цифрового покоління. Завдяки використанню цифрових інструментів іншомовна підготовка військових фахівців Збройних Сил України стає більш доступною і комфортною, що вкрай важливо за умов мінімальних затрат: часових, фінансових, людських ресурсів. А для сучасного слухача ВВНЗ - це ще й інтерактивний майданчик для професійного розвитку, реалізації своєї індивідуальної траєкторії навчання та кар'єрного зросту.

\title{
Література:
}

1. Аврамчук А.М., Використання сервісу h5p для викладання мовних дисциплін. URL: : https://lib.iitta.gov.ua/709695/1/Avramchuk \%20(pdf.io).pdf дата звернення: 05.04.2021).

2. МОН Активно Долучається До Проєктів Цифрової Трансформації. 19 лютого 2021 року. URL: https://mon.gov.ua/ua/news/mon-aktivno-doluchayetsya-do-proyektivcifrovoyi-transformaciyi (дата звернення: 05.04.2021).

3. Toader, T.; Safta, M.; Titiris, C.; Firtescu, B. Effects of Digitalisation on Higher Education in a Sustainable Development Framework - Online Learning Challenges during the COVID-19 Pandemic. Sustainability. 2021. № 13, 6444. https://doi.org/10.3390/ su1311644

DOI https://doi.org/10.30525/978-9934-26-146-6-22

\section{ДИСТАНЦІЙНЕ НАВЧАННЯ В КОНТЕКСТІ РОЗВИТКУ ПРАВОВОЇ КОМПЕТЕНТНОСТІ ПЕДАГОГІЧНИХ ПРАЦІВНИКІВ ЕКОНОМІЧНИХ КОЛЕДЖІВ}

\author{
Курок Р. О. \\ кандидат юридичних наук, доцент, \\ молодиий науковий співробітник \\ лабораторії науково-методичного супроводу підготовки фахівиів \\ у коледжах і технікумах \\ Інститут професійно-технічної освіти \\ Начіональної академії педагогічних наук України \\ м. Київ, Україна
}

Аналізуючи практику впровадження інновацій в сучасній освітній діяльності в контексті розвитку правової компетентності педагогічних працівників економічних коледжів, ми можемо констатувати, що одним 
3 основник складників цього процесу $є$ використання інформаційнокомунікаційних технологій.

Цей процес є цілком природнім, оскільки освіта не може залишатися осторонь сучасних трендів інформатизації і глобалізації суспільства. Досягнення технічного прогресу проникають у всі сфери життєдіяльності суспільства, в тому числі й освітню діяльність, що відкриває для неї нові можливості та перспективи. Повсякденне користування персональними комп'ютерами, ноутбуками, планшетами, мобільними телефонами стало нормою для сучасної людини. Всі ці пристрої об’єднані мережею інтернет можуть i повинні використовуватись для задоволення освітніх й інформаційних потреб особи. Тому тенденція щодо широкого застосування інформаційнокомунікаційних технологій в освітній діяльності в найближчому майбутньому буде тільки посилюватись.

За О. Федоренко, «інформаційно-комунікаційні технології $\epsilon$ інноваційними педагогічними технологіями системи освіти, що застосовуються для створення нових можливостей передачі знань (діяльності педагога), сприйняття знань (діяльності тих, хто навчається), оцінки якості навчання та всебічного розвитку особистості в ході навчально-виховного процесу, робить освітній процес більш інтенсивним i продуктивним за рахунок використання можливостей мультимедіа, соціальних мереж, употужнює міжпредметні зв'язки, забезпечує пошук та використання інформації з різноманітних джерел, утворює зручні обставини для спілкування у найбільш прийнятній формі» [1, с. 9].

Серед основних переваг використання інформаційнокомунікаційних технологій в освітньому процесі є:

- можливість вибору індивідуальної траєкторії навчання, доступ до освітніх послуг з будь-якої точки світу;

- урізноманітнення форм, методів і засобів подачі інформації;

- доступність великих масивів інформації, можливість оперативного обміну інформацією;

- інтенсифікація освітнього процесу, можливості застосування сучасних технологій навчання;

- мотивація до пошукової діяльності, удосконалення інформаційнокомунікативної компетентності;

- можливість здійснення оперативного контролю знань;

- розвиток умінь самостійного прийняття рішень, прогнозування їх наслідків;

- стимулювання самостійної роботи та інші. 
Упровадженню інформаційно-комунікаційних технологій буде сприяти покращення матеріально-технічної бази закладів освіти, підвищення інформаційно-комунікативної культури педагогічних працівників, забезпечення необхідним програмним забезпеченням, створення інформаційних банків даних 3 навчальною, методичною, науковою літературою та ціла низка інших організаційних та управлінських рішень.

Одним з видів інноваційних технологій, що може бути використаним педагогічними працівниками економічних коледжів для розвитку правової компетентності та здійснюється з залученням інформаційнокомунікаційних технологій, є дистанційне навчання.

Закон України «Про освіту» визначає дистанційну форма здобуття освіти як «індивідуалізований процес здобуття освіти, який відбувається в основному за опосередкованої взаємодії віддалених один від одного учасників освітнього процесу в спеціалізованому середовищі, що функціонує на базі сучасних психолого-педагогічних та інформаційнокомунікаційних технологій» [2].

Методика освітньої діяльності 3 використанням технологій дистанційного навчання заснована на використанні спеціального інформаційно-освітнього середовища, яке включає:

- систему засобів забезпечення взаємодії суб'єктів процесу дистанційного навчання - слухачів і викладачів;

- навчальні матеріали, сформовані у вигляді навчальних курсів, розташованих в мережі Інтернет, в яких розкривається основний зміст навчання, вправи, матеріали для контролю знань;

- засоби для забезпечення доступу до додаткових джерел даних: електронних бібліотек, відео- і аудіотек [3, с. 31].

Технологія дистанційного навчання базується на системному підході та комплексних навчальних технологіях, широкому застосуванні розподілу навчальної праці й мережевих форм організації управління освітнім процесом, що в підсумку дає змогу підвищити рівень і якість надання освітніх послуг [4, с. 406].

Курс дистанційного навчання можна розділити на взаємопов'язані етапи:

1) надання інформаційних матеріалів та завдань;

2) контроль результатів навчання;

3) управління освітнім процесом.

Правова інформація та завдання для самостійної роботи, необхідні для розвитку правової компетентності педагогічних працівників економічних коледжів, можуть надаватись безпосередньо викладачемтьютором в режимі он-лайн, або розміщуватись на відповідних вебсайтах, освітніх платформах чи хмарних сервісах. При цьому інформація 
надається у вигляді інформаційного блоку, відповідно до тематики курсу дистанційного навчання.

Важливо, щоб інформаційні блоки мали логічну послідовність та містили актуальну правову інформацію, необхідну для ефективного здійснення професійної діяльності педагогічними працівниками економічних коледжів, а також законодавчі та підзаконні акти економічного спрямування за профілем викладання закріплених навчальних дисциплін. Під час виконання самостійних завдань, у разі виникнення труднощів 3 їх опрацюванням, слухач завжди має можливість звернутись за консультацією до викладача-тьютора за попередньо відпрацьованими способами зв'язку.

Після опрацювання інформаційного масиву та виконання завдань для самостійної роботи з метою оцінювання якості засвоєння навчального матеріалу відбувається контроль результатів навчання. При цьому, можуть застосовуватись різноманітні форми контролю. Зокрема, це може бути вирішення тесових завдань, ситуаційних задач, кейсів тощо.

За результатами контрольних заходів на етапі управління приймається рішення щодо переходу до нового інформаційного блоку, завершення курсу навчання або повернення до попереднього інформаційного масиву з метою його додаткового опрацювання.

Для здійснення контакту слухачів та викладачів-тьюторів можуть використовуватися такі інтрнет-платформи: Zoom, Google Classroom, Google Hangouts, Moodle, Skype, DingTalk, YouTube та інші.

Основними видами навчальних занять із застосуванням webтехнологій, що можуть використовуватись під час дистанційного навчання з розвитку правової компетентності педагогічних працівників економічних коледжів, $\epsilon$ :

- вебінари - заняття, під час якого відбувається безпосередня взаємодія викладача з аудиторією;

- вебкасти - заняття, які приводяться в режимі реального часу та не передбачають обговорення питань, які доводяться лектором;

- онлайн-лекції - різновид лекційних занять, під час яких лектор доводить інформацію відповідно до тематики курсу дистанційного навчання. При цьому, заняття може бути розміщеним на відповідних інтернет ресурсах та доступним для перегляду в зручний час для слухачів курсів.

\section{Література:}

1. Федоренко О. Г., Рожков С. I. Інформаційно-комунікаційні технології як запорука підвищення якості підготовки майбутнього фахівця. Науковий вісник Донбасу. 2019. № 1-2 (39-40). URL: http://nvd.luguniv.edu.ua/archiv/2019/N1-2(39-40)/fogpmf.PDF ～(дата звернення: 08.05.2021). 
2. Про освіту. Закон України 05.09.2017 p. № 2145-VIII. Дата оновлення: 01.01.2021. URL: https://zakon.rada.gov.ua/laws/show/214519\#Техt (дата звернення: 31.01.2021).

3. Біляй Ю. П. Методична система підготовки майбутніх вчителів математики та інформатики до використання технологій дистанційного навчання : дис. ... канд. пед. наук : 13.00.02. Київ, 2018. 256 с.

4. Радкевич О. П. Теоретичні і методичні основи розвитку правової культури педагогічних працівників закладів професійної освіти : дис. ... д-ра пед. наук: 13.00.04. Київ, 2020. 587 с.

DOI https://doi.org/10.30525/978-9934-26-146-6-23

\title{
ЗАБЕЗПЕЧЕННЯ ЯКОСТІ НАЗЕМНОГО НАВЧАННЯ БОЙОВИМ ПОЛЬОТАМ МАЙБУТНІХ ЛЬОТЧИКІВ ТАКТИЧНОЇ АВІАЦІЇ ЯК ПЕДАГОГІЧНА СИСТЕМА: ОБГРУНТУВАННЯ ПІДХОДУ
}

\author{
Невзоров Р. В. \\ начальник кафедри тактики авіаиії \\ Харківський начіональний університет \\ Повітряних Сил імені Івана Кожедуба \\ м. Харків, Украӥна
}

Надзвичайно стрімкій характер розвитку освітніх процесів з однієї сторони та динамічний прогрес технологій в авіаційній сфері з іншої у XXI ст. чинять об’єктивний вплив на систему фахової підготовки військово-авіаційних спеціалістів в Україні, доповнений новітніми військово-політичними викликами, пов'язаними із загрозою територіальної цілісності й основам національної державності. Реальність, в тому числі, вимагає критичної ревізії підходів, теорії і практики підготовки майбутніх льотчиків тактичної авіації у вітчизняному вищому військовому закладі освіти (в Україні таким профільним закладом, що здійснює підготовку військових льотчиків $є$ Харківський національний університет Повітряних Сил імені Івана Кожедуба). Вказані чинники, а також орієнтир української вищої військової освіти на аналогічний досвід Євроатлантичного Альянсу актуалізують військово-педагогічні дослідження в області забезпечення якості фахової підготовки курсантів-військових льотчиків в цілому та іiї окремих складових зокрема. 